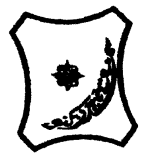

Bayero Journal of Pure and Applied Sciences, 10(2): 209 - 221

Received: November, 2017

Accepted: December, 2017

ISSN $2006-6996$

\title{
ELECTRICAL RESISTIVITY INVESTIGATION OF SUB-SURFACE TOPOGRAPHY OF RAFIN BAREDA DRAINAGE BASIN AS A TOOL FOR CASSITERITE-COLUMBITE EXPLORATION IN DUTSEN-WAI, NIGERIA
}

\author{
Umar, M., ${ }^{1}{ }^{1}$, Ahmed, A. L., ${ }^{2}$ Magaji, S. S. ${ }^{3}$ and Bala, B. ${ }^{4}$ \\ ${ }^{1,2,4} \mathbf{A}$ Department of physics Ahmadu Bello University Zaria \\ ${ }^{3}$ Department of Geology Ahmadu Bello University Zaria \\ *Correspondence Author: Tel. +2348036865363; umardk06@yahoo.com
}

\begin{abstract}
Geophysical investigation has been undertaken at Rafin-Bareda drainage basin with the aim of identifying suitable points of high Cassiterite potential for the study area. The people around such drainage basin exploit these cassiterite and columbite deposits by trial and error method.The trial and error process of mining is dangerous to the lives of the miners.Hence, a Schlumberger array with half current electrode spacing ranging $1-100 m$ was used. A total of 36 vertical electrical sounding (VES) stations were equally spaced at $\mathbf{2 0} \mathrm{m}$ interval along eight profiles in the area using Ohmega terrameter. The field data were interpreted using IPI2WINsoftware. The results obtained from the obtained VES data were applied to produce the geoelectric sections of the study area, which indicate a 2-4 range of geoelectrical layers. The corresponding geologic section comprises of sandy clay soil, weathered and fresh laterite, weathered and fresh basement as the main rock types. The 3D surface of the basement topography of the study area shows the undulating nature of the bedrock subsurface with the position of the various VES points. These enabled us to determine zones with high cassiterite potential and the best location for drilling productive cassiterite in the area. The depth to the basement rock, resistivity and thickness values ranged

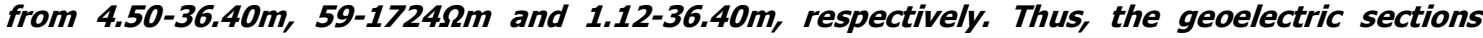
suggest that the point of high depression on the basement rock represents a promising area for Cassiterite-Columbite. The Cassiterite mineralization map identifies the VES points with high cassiterite potential.
\end{abstract}

Keyword: Geological profiles, Vertical electric sounding (VES), Cassiterite-Columbite,Dutsen-wai drainage.

\section{INTRODUCTION}

The Dutsen-Wai complex is a small $\left(6.3 \mathrm{~km}^{2}\right)$ ring complex located about $64 \mathrm{~km}$ east-southeast of Zaria near Dutsen-Wai village in the northwestern corner of the Nigerian Younger Granite Province (Fig. 2) (Ajakaiye, 1974). It is a typical member of the younger granites in that the exposure is dominated by nonerogenic discordant high-level strongly alkaline intrusives of probable Jurassic age which taken together are roughly circular in plan (Van Breeman and Bowden, 1973; Jacobson and MacLeod, 1977). Conclusions regarding petrogenesis and mode of emplacement of several ring complexes within the Younger Granite Province are based on surficial petrological and structural relationships (Turner 1963, 1972; Oyawoye, 1968; Jacobson and MacLeod, 1977) and geochronological (Van Breeman and Bowden, 1973) and experimental petrological studies (Brown and Bowden, 1973).

Exploration of mineral resources has assumed prime importance in several developing countries including Nigeria (Akanbi, 2012). Nigeria is endowed with abundant mineral resources, which have contributed immensely to the national wealth which has improved the socio-economic benefits of the people (Akanbi, 2012). The mineral Cassiterite, $\mathrm{SnO}_{2}$, is the most important ore of tin. It is often found in hydrothermal veins or pegmatites but also form as a result of secondary processes in oxidation zone of weathered tin deposit (Abubakre, 2009). Cassiterite can wear down to nodules and large grains that are eventually concentrated in placer deposit. In several occasions, after extreme rainfall events the soil surface can be denudated and sediment layers can be weathered and eroded such as in Mediterranean areas (Rodrigo Comino et al., 2016). The nodules have a greasy luster and seem to be heavy in the hand. Some cassiterites are very black and hence tests are sometimes essential.

Tin mineralization in Nigeria occurs within the Younger Granite province of Nigeria.The geological setting, structure and other features of Younger Granite Complexes in Northern Nigeria have been extensively described as the main sources of Cassiterite and Columbite in Nigeria (Falconer 1921, Falconer and Raeburn 1923, Jacobson 1943, Macleod 1971). Unlike the Basement complex rocks, the Younger Granite emplacement was associated with phase of mineralization. The economic minerals like Arsenopyrite, Chalcopyrite, Cassiterite, Columbite and Tantalite occur within and around the Younger Granite Complexes (Aina, 1992). These are mine in Ririwai Complex, Banke Complex, Dutsen-wai Complex and Tibchi Complex. 
Bajopas Volume 10 Number 2 December, 2017

Tin mining has a very long history in Jos, Plateau State. The most productive of this area is the Jos Bukuru Complex which yielded a substantial portion of Cassiterite so far mined in Nigeria. Tin mining started in 1904 and by the mid-1920s more Cassiterite (tin ore) discoveries had been carried out which resulted in more mechanized extraction techniques to meet the high demand for tin by 1960s (Akanbi, 2012). The demand increased, got to a peak and gradually declined in the late 1980s.

Recently, the world demand for tin is quite steady, and is growing at about 5\% a year (Cowie, 2010).Ring Complexes of Nigeria are among those magmatic metallogenic provinces where there are a number of genetic types of primary mineralization linked with the same period of magmatic activity. Two types of tin mineralization were identified, the primary deposits found as dissemination in biotite granite and pegmatities which comprises of the late magmatic dissemination and the hydrothermal mineralization and placer deposit found among gravels pockets in both ancient and modern stream channels (Pastor, 1985). The only important primary deposits, extensively explored for several years are at Ririwai (Pastor, 1985). Most sources of Cassiterite today are found in alluvial or placer deposits containing the resistant weathered grain.

The Younger Granite Complex of the Dutsen-wai and surrounding areas are richly mineralized with alluvial cassiterite. Cassiterite is associated with other mineral such as columbite, monazite and accessories like zircon and topaz (Akanbi, 2012). Consequently, a lot of mining activities (formal and informal) have been carried out over many years in the area. Many of these mining activities carried out presently are done by trial and error means (fig. 14-17).

The Rafin Bareda drainage basin contains alluvial deposits formed from weathering and erosion of the primary deposits of Dutsen-Wai ring complex, which is one of the sources of cassiterite-columbite. The weathered cassiterite and columbite are trapped in the topographic lows within drainage basin as sink. The people around such drainage basin exploit these cassiterite and columbite deposits by trial and error method (fig. 14-17).

Artisanal cassiterite mining is a major source of employment for people residing in areas within the Nigerian Younger Granite Province. Despite the importance of this means of livelihood artisanal miners do not have any scientific method of detecting areas of high cassiterite potential; hence they resort to trial and error methods. The most significant uses of cassiterite are in electronic industries such as circuit-board for television, computers microwave oven etc. Tin-plating which is used as a protective coating on steel cans, for production of bronze and various chemical processes. It is also used in lithium ion batteries (Cowie, 2010).

Geophysical technique has been found very useful in many areas such as mineral exploration, groundwater investigation and some environmental studies. It involves studying the physical properties of the earth in order to provide vital information on the subsurface material condition for numerous practical applications. In this research, vertical electrical sounding of electrical resistivity is used to assess the cassiterite mineralization of the area and determined; (i) the thickness of the alluvial sediment within the drainage basin (ii) the work-out sub-surface basement topography that act as trap for cassiterite; and (iii) the production of the cassiterite mineralization potential map of the drainage basin.These are performed by taking measurement at or near the earth surface that are influenced by internal distribution of physical properties. Consequently, analysis of these measurements can reveal how the physical properties of the earth's interior vary vertically and laterally, which reflect the subsurface geology. Another method of investigating subsurface geology was by drilling and pitting which provide information only at discrete location and are usually very expensive.

\section{MATERIALS AND METHODS}

The geophysical investigation involved the use of vertical electric sounding (VES) method. Vertical electric sounding furnishes information concerning the vertical succession of different conducting zones and resistivities (Ekwe et al., 2010). By measuring the electrical resistance to a direct current applied at the surface, this geophysical method can be used to locate fracture zones, faults and other preferred groundwater/contaminant pathways; locate clay, sand channels and locate perched water zones and depth to the bedrock (Sultan, 2012). Thirty-six (36) vertical electric sounding (VES) locations in (Fig.1) were occupied across the drainage basin and along a void near the drainage basin utilizing the schlumberger electrode configuration. The quantitative interpretation involved partial curve marching technique (Zohdy, 1965) using the ipi2winsoftware. The principal instrument used for this survey is the omega terrameter. The resistance readings are displaced on the digital readout screen and then written down on the field report book. 


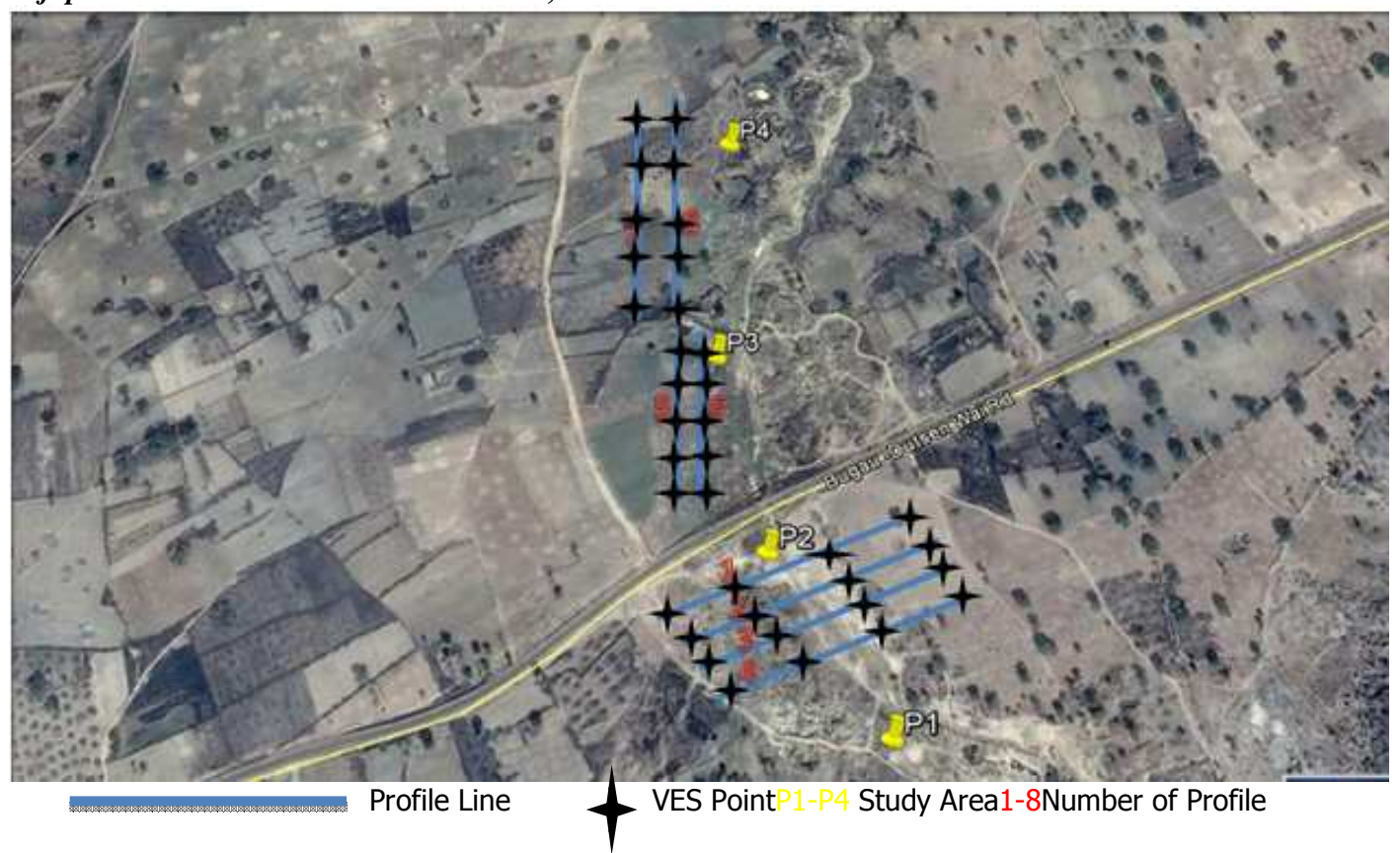

Figure: 1. Profiles layout (Google earth image)

\section{Location of the study area}

The Dutsen-Wai complex is a small $\left(6.3 \mathrm{~km}^{2}\right)$ ring complex located about $64 \mathrm{~km}$ east-southeast of Zaria near Dutsen-Wai village in the northwestern corner of the Nigerian Younger Granite Province (Fig. 2) (Ajakaiye, 1974). It is a typical member of the younger granites in that the exposure is dominated by nonerogenic discordant high-level strongly alkaline intrusives of probable Jurassic age which taken together are roughly circular in plan (Van Breeman and Bowden, 1973; Jacobson and MacLeod, 1977). Conclusions regarding petrogenesis and mode of emplacement of several ring complexes within the Younger Granite Province are based on surficial petrological and structural relationships (Turner 1963, 1972; Oyawoye, 1968; Jacobson and MacLeod, 1977) and geochronological (Van Breeman and Bowden, 1973) and experimental petrological studies (Brown and Bowden, 1973). The area of the study RafinBareda drainage basin is near Dutsen-wai Complex, in Kubau local government of Kaduna State in (Fig.1). The Dutsen-wai Complex rises to about $120 \mathrm{~m}$ above the surrounding plains (Ahmed, 2006).

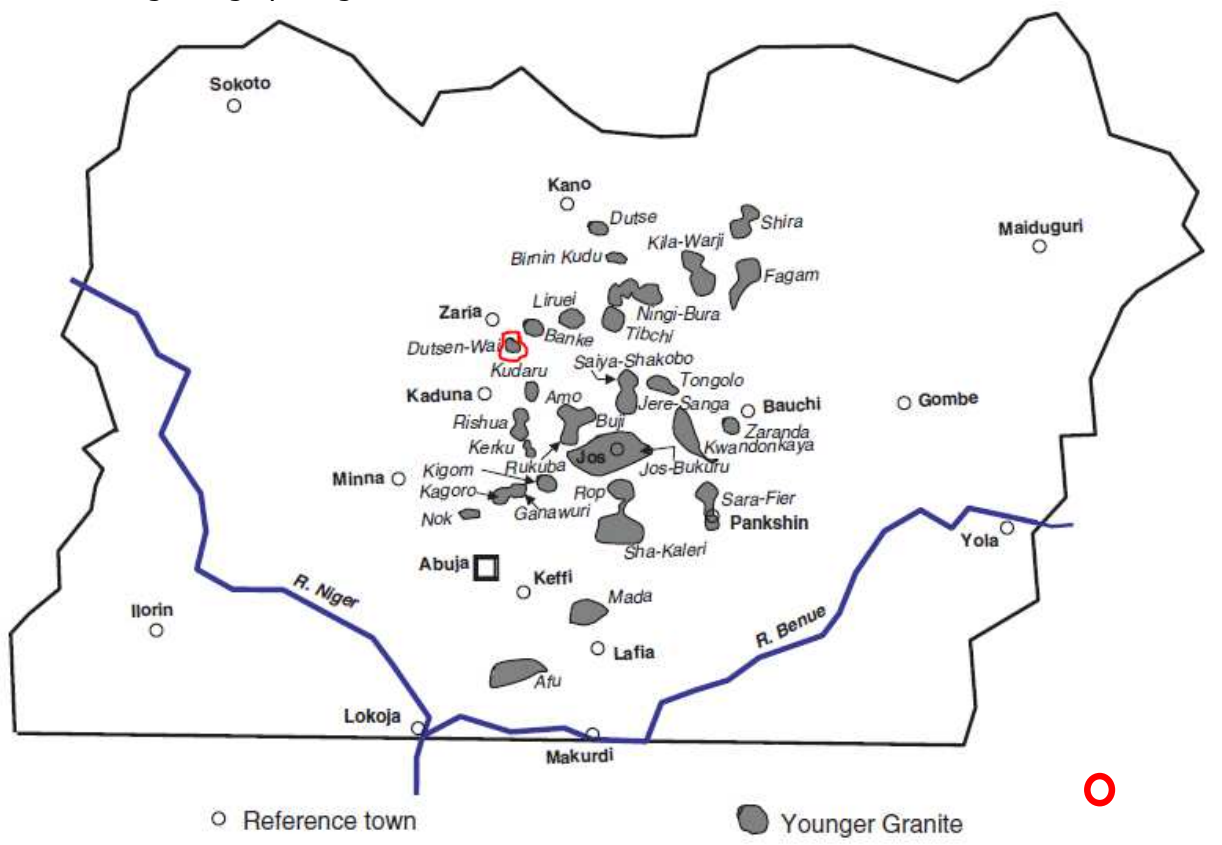

Figure 2: Major Younger Granites localities in Nigeria (Obaje, 2009). 


\section{Climate and Vegetation}

The Dutsen-wai area is located on a plateau at a height between $120 \mathrm{~m}$ and $150 \mathrm{~m}$ and has a tropical continental climate (Ologe, 1971). The area is characterized by two seasons, wet and dry. The wet season lasts since April until October, registering during August having the highest rainfall amountsmeanwhile the dry season extents from November to March.

The mean annual surface temperature varies from about $25^{\circ} \mathrm{C}$ to $35^{\circ} \mathrm{C}$. The temperatures generally decrease in July and August corresponding to the peak of rainy season, as well as in December and January periods corresponding to the peak of harmattan (cold) in the area (Ahmed, 2006). The vegetation is that of Sudan Savannah characterized by grasses, shrubs, thorns and scattered trees.

\section{Geology of the area}

The Dutsen-Wai complex is intruded into an undifferentiated amphibolite grade basement composed of migmatites and granitic gneisses (Ajakaiye, 1974). Three major igneous units common to the younger granite suite make up the exposure and exhibit sharp mutual contacts (Raeburn et al., 1927; Turner, 1972; Jacobson and MacLeod, 1977). Volcanics, biotite granite and albite riebeckite granite are in chronological order. Remnants of an initial volcanic phase are preserved as a narrow outcrop of explosion breccia $600 \mathrm{~m}$ long and up to $60 \mathrm{~m}$ wide composed entirely of basement rock fragments up to $0.3 \mathrm{~m}$ in diameter along the southern flank of the complex (Jacobson and MacLeod, 1977). The main intrusive forms $80 \%$ of the exposed complex (Fig. 3) and is nonporphyritic fine to medium-grained biotite granite, which has a homogeneous macroscopic texture and composition (Jacobson and MacLeod, 1977). Its well-developed north-northwest joint system controls drainage in the immediate vicinity of its outcrop (Ajakaiye, 1974). The most prominent of these lineations occurs as a broad steep-sided flat- bottomed valley up to $1 \mathrm{~km}$ wide containing an underfit stream which drains to the northwest from the central part of the biotite granite exposure (Fig.3).The biotite granite is the main source of the tin deposits mined on a very small scale in the area although (Raeburn et al., 1927) noted that the complex exhibited excessive tin mineralization for its outcrop size. Tin deposits are typically associated with biotite granite throughout the Younger Granite Province. A later intrusion of albite riebeckite granite, which is poorly exposed, flanks the biotite granite on its east side (Fig. 3). It is extremely variable in texture but is compositionally homogeneous except in the degree of late stage albitization (Jacobson and MacLeod, 1977). Contacts with the basement rocks to the east are poorly defined. Remnants of aegerine commonly form the cores of riebeckite grains. Several felsitic dikes (mostly biotite microgranites) associated with the biotite granite (Jacobson and MacLeod, 1977) cut the granite as well as basement rocks adjacent to the southern and eastern margins of the complex. The sequence of extrusive and intrusive igneous events in the province is well documented (Turner, 1963, 1972) and consists of an initial predominantly acidic volcanic phase accompanied or immediately followed by the formation of a peripheral vertical-sided ring fracture which broke the surface and which was filled, in most cases, with granite porphyry upon subsidence of the rocks interior to the ring fracture. A long waning felsic intrusive phase followed. In the case of the Dutsen-Wai complex, the present outcrop limits give the probable extent of the associated initial ring fracture (Fig. 3). Ring fracture followed by cauldron subsidence is considered to be the major mode of intrusive emplacement for the younger granites and is thought to give rise to plutons roughly circular in plan with generally steeply dipping contacts (Turner, 1963, 1972; Black and Girod, 1973; Jacobson and MacLeod, 1977).

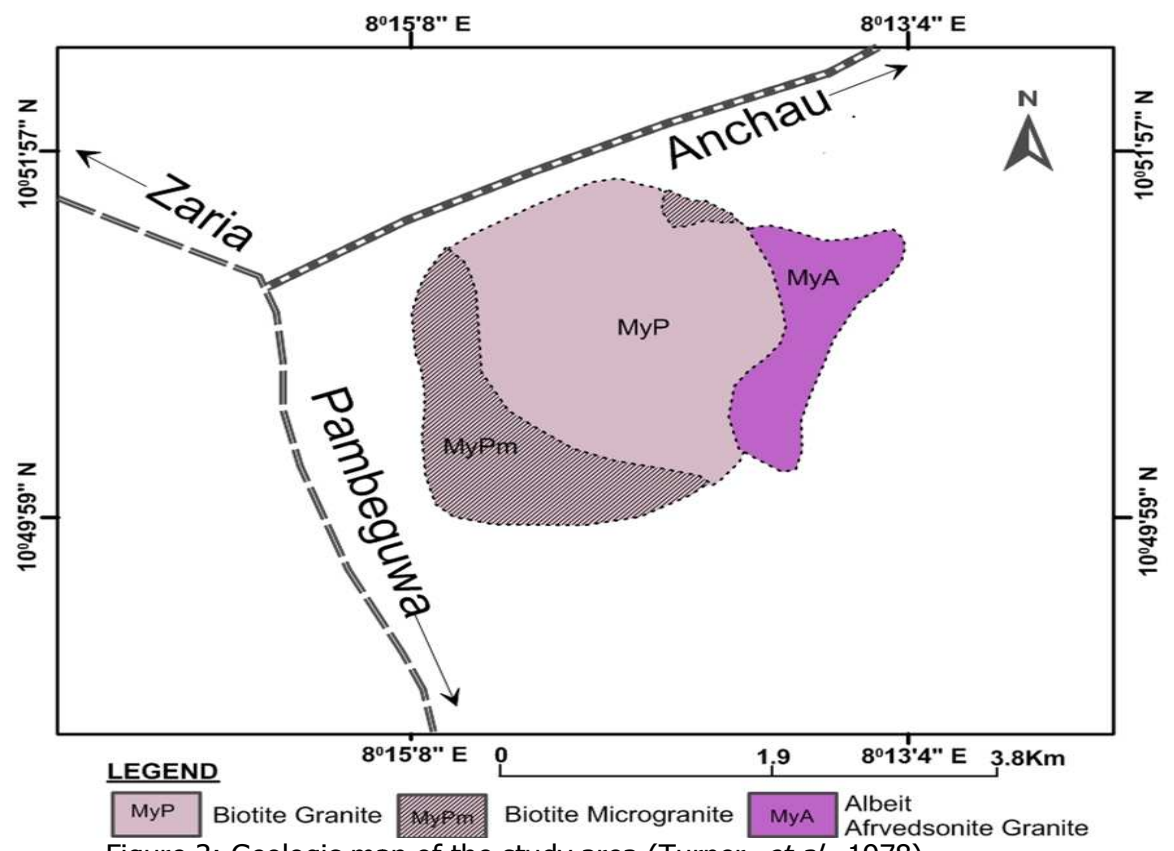

Figure 3: Geologic map of the study area (Turner, et al., 1978) 


\section{General Principle of Resistivity Method}

The resistivity method is based on measuring the potentials between one electrode pair while transmitting direct current (DC) between another electrode pair. Resistivity measurements separate the subsurface into different layers based on their resistivity values (Ekwe et, al., 2010). The depth of penetration is proportional to the separation between the electrodes, in homogeneous ground, and varying the electrode separation provides information about the stratification of the ground.

Fig.4 shows the current and potential difference distribution within a homogeneous isotropic ground in a vertical plane through the current electrodes $\mathrm{C} 1$ and $\mathrm{C} 2$ and potential electrode $\mathrm{P}_{1}$ and $\mathrm{P}_{2}$. When an external voltage is applied across them, there will be a flow of current through the earth from one electrode $\mathrm{C} 1$ to the other, $\mathrm{C} 2$. The resistivity method is based on measuring the potential between one electrode pair (P1 and P2, called potential electrodes) while transmitting $\mathrm{DC}$ between another electrode pair (C1 and C2) and $r_{1}, r_{2}, r_{3}$ and $r_{4}$ are the electrode separations. The rheostat varies the current I which is measured by the ammeter $(A)$ while the voltmeter $(V)$ measures the potential difference $\Delta U$.

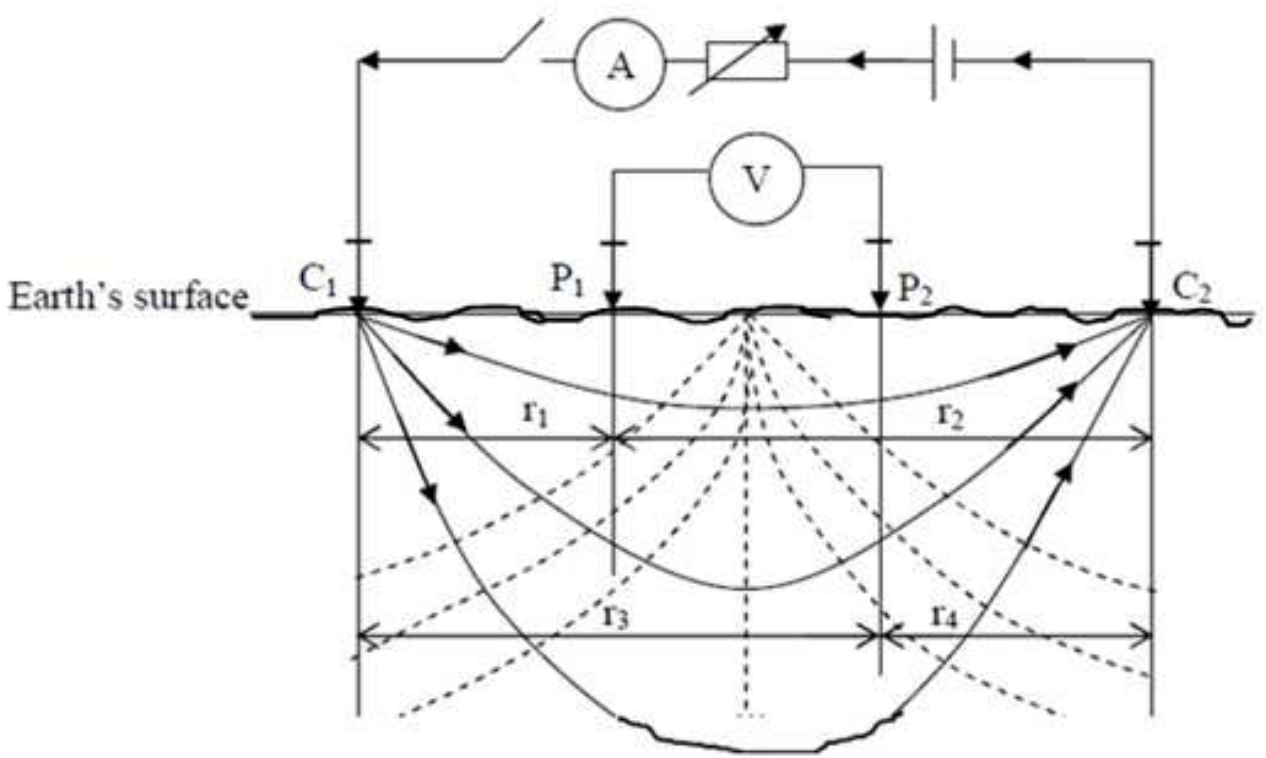

Figure 4: Current and Potential Distributions within Homogeneous Isotropic ground.

\section{Vertical Electrical Sounding (VES)}

This is also known as electrical drilling or expanding probe. It is used mainly in the study of horizontal or near horizontal interfaces. In this method the current and potential electrodes are maintained at the same relative spacing and the whole spread is progressively expanded about a fixed central point. Consequently, readings are taken as the current reaches progressively greater depth.

The measured apparent resistivity values are normally plotted against electrode spacing values on a log-log graph paper. To interpret the data from such a survey, it is normally assumed that the subsurface consists of horizontal layers. In this case, the subsurface resistivity changes only with depth, but does not change in the horizontal direction.

In many engineering and environmental studies, the subsurface geology is very complex where the resistivity can change rapidly over short distances. The resistivity sounding method might not be sufficiently accurate for such situations. However, the technique is extensively used in geotechnical surveys to determine overburden thickness and also in hydrogeology to define horizontal zones of porous strata.

\section{RESULTS}

For better understanding, the results of investigation are usually presented in the form of geoelectrical cross-sections. However, the topsoil and the weathered basement are regarded as the overburden while the bedrock consists of the fracture and the fresh basement rocks (Oladapo, 2013). Therefore, in accordance with above fact, eightgeoelectrical crosssections (Figure 5-12) were performed along a profile (1-8) and will be interpreted as... 
Bajopas Volume 10 Number 2 December, 2017

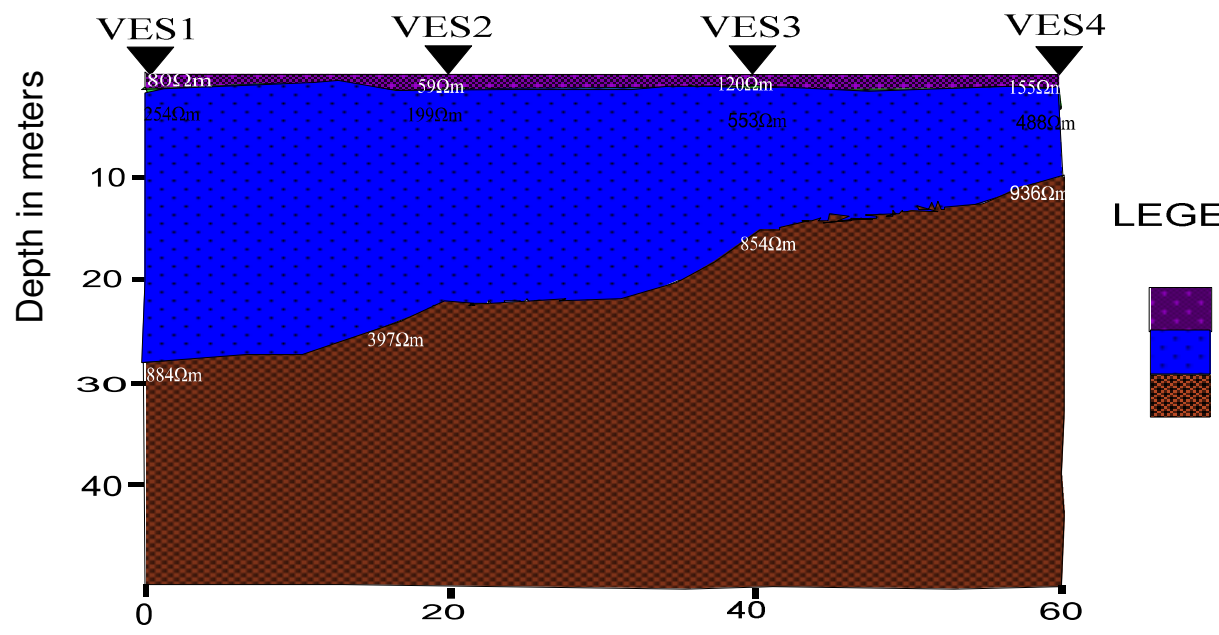

op soil

Weathered basement Fresh basement

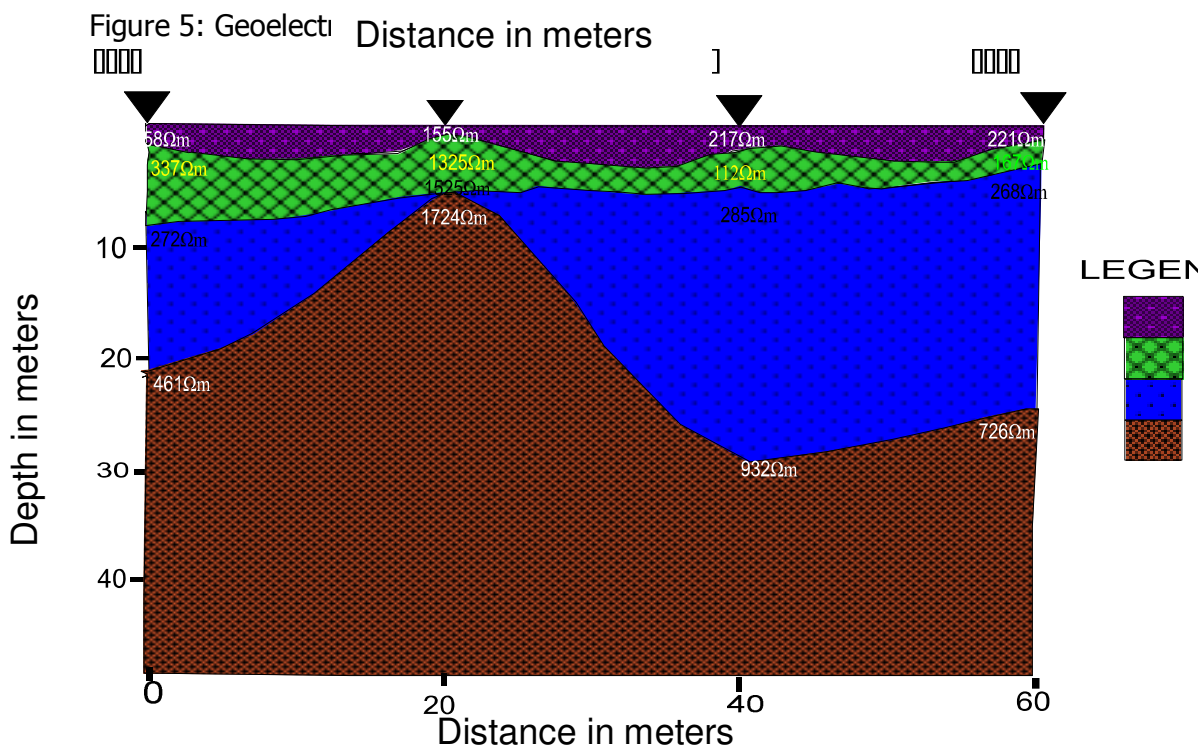

Top soil

Sandy clayed, silt sand Weathered basement Fresh basement

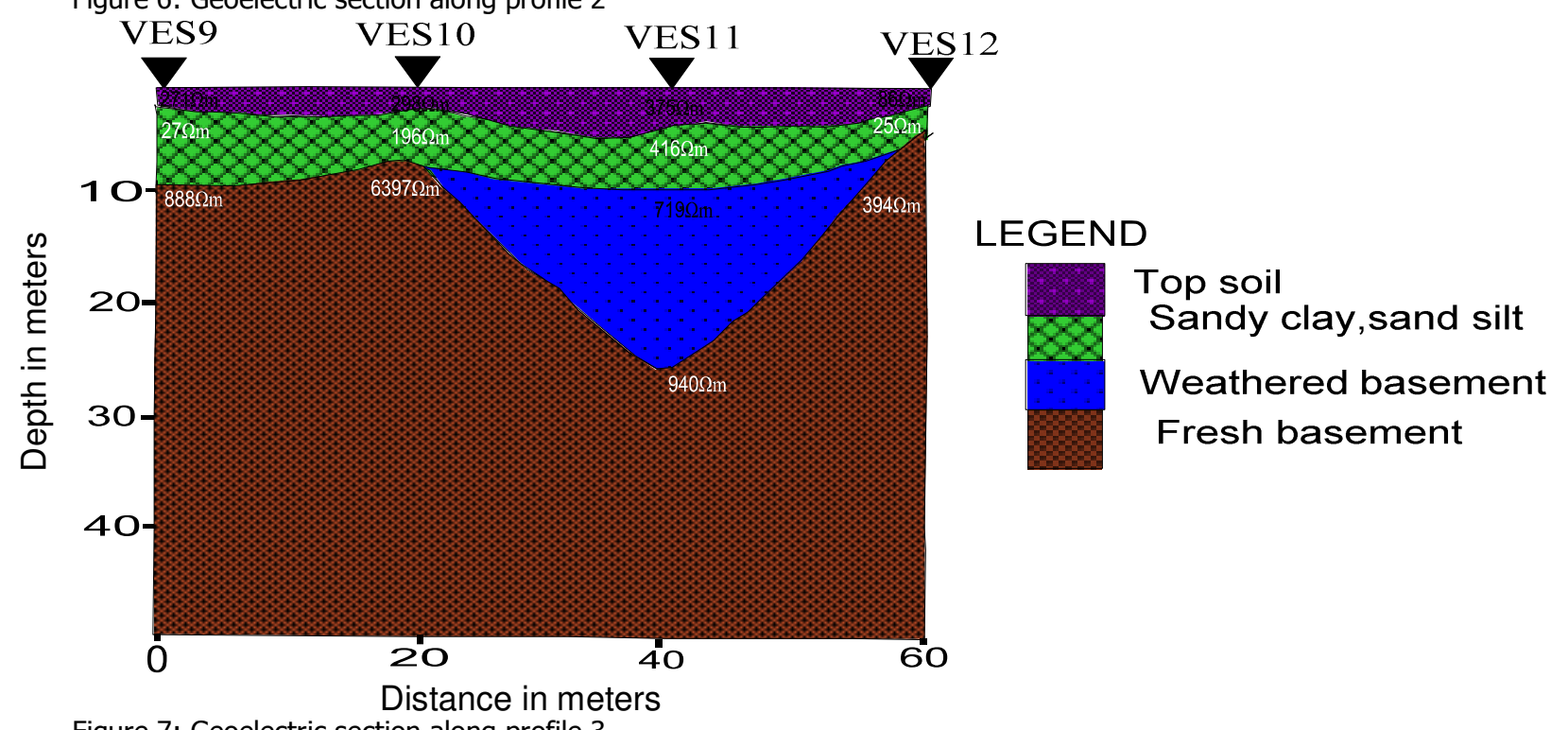

Figure 7: Geoelectric section along profile 3 


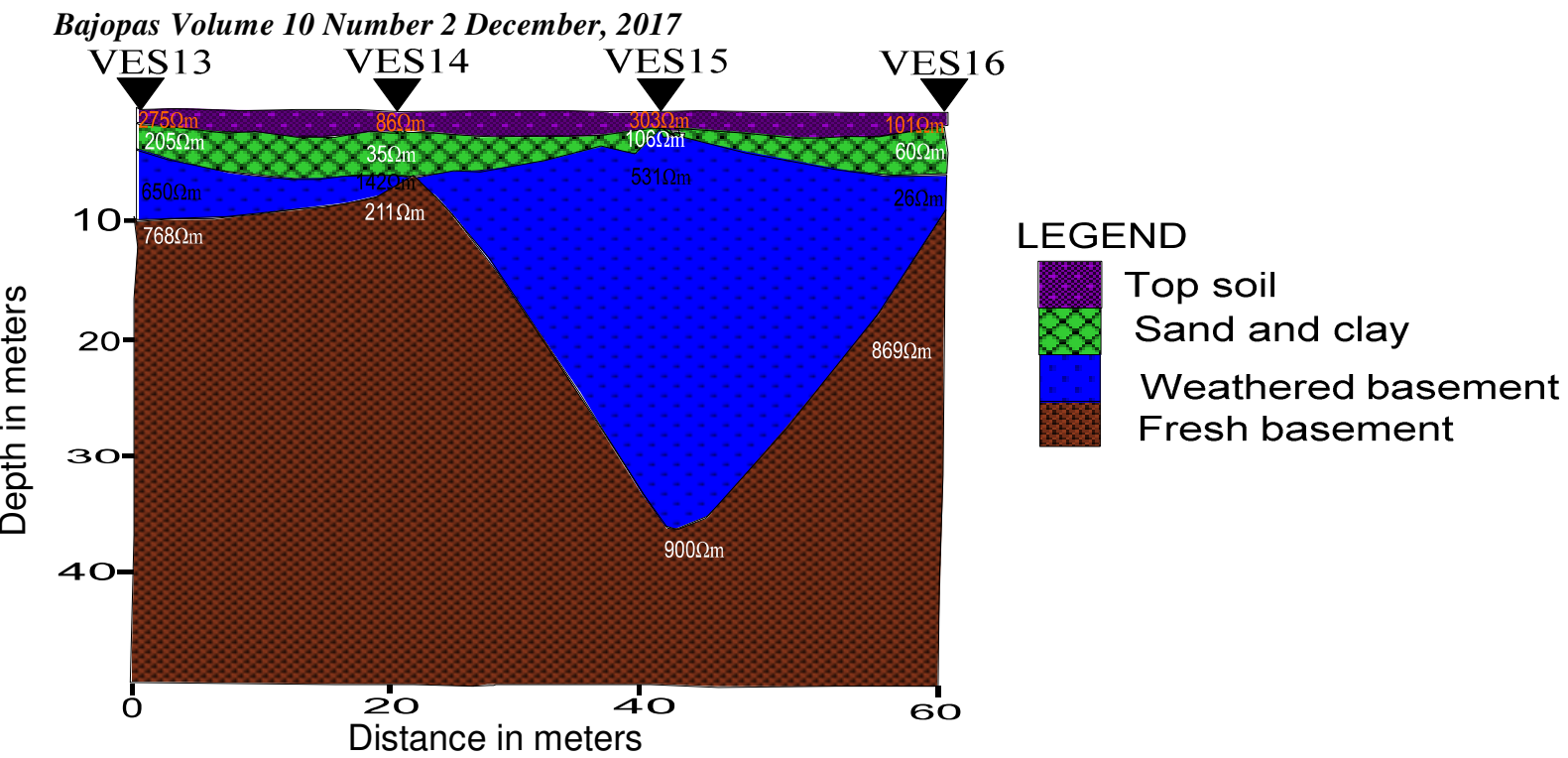

Figure 8: Geoelectric section along profile 4

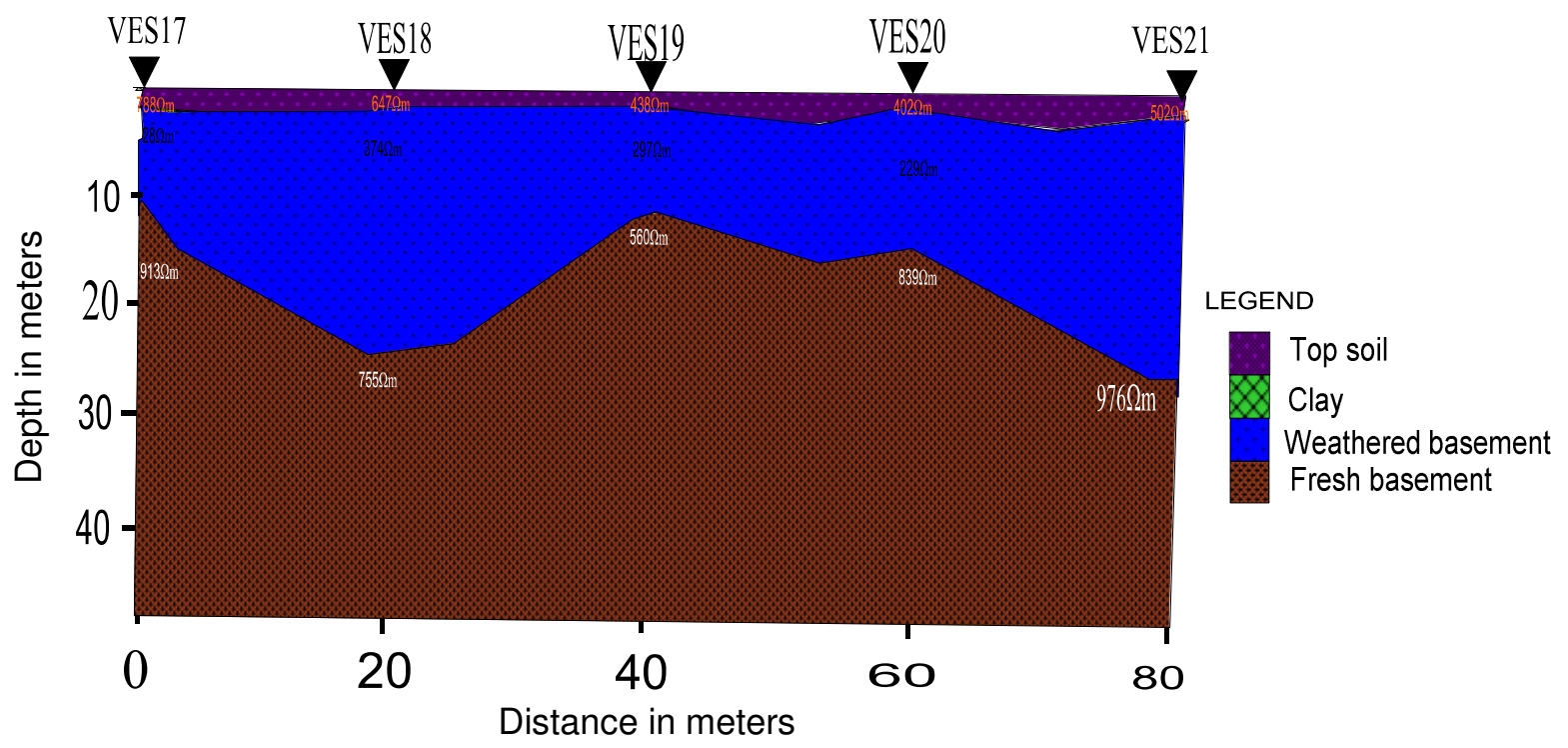

Figure 9: Geoelectric section along profile 5

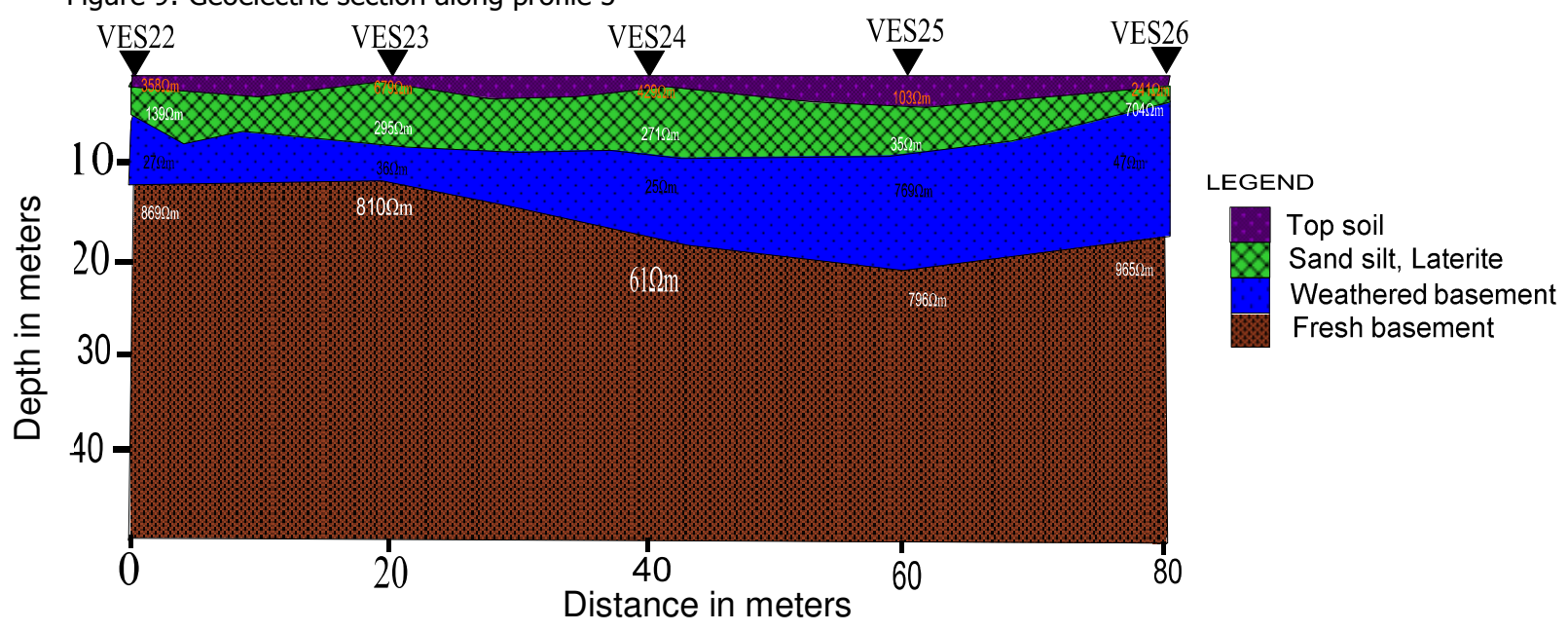

Figure 10: Geoelectric section along profile 6 
Bajopas Volume 10 Number 2 December, 2017

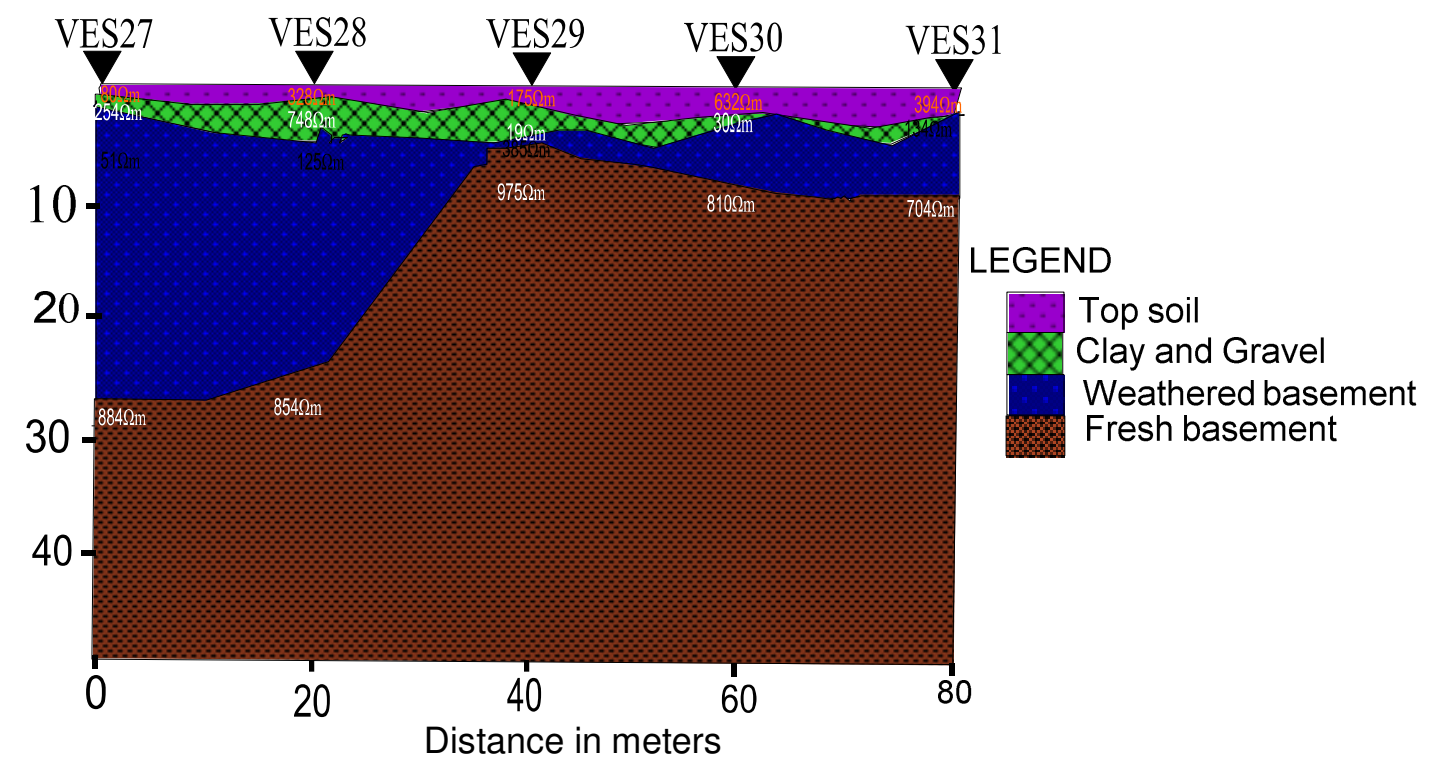

Figure 11: Geoelectric section along profile 7

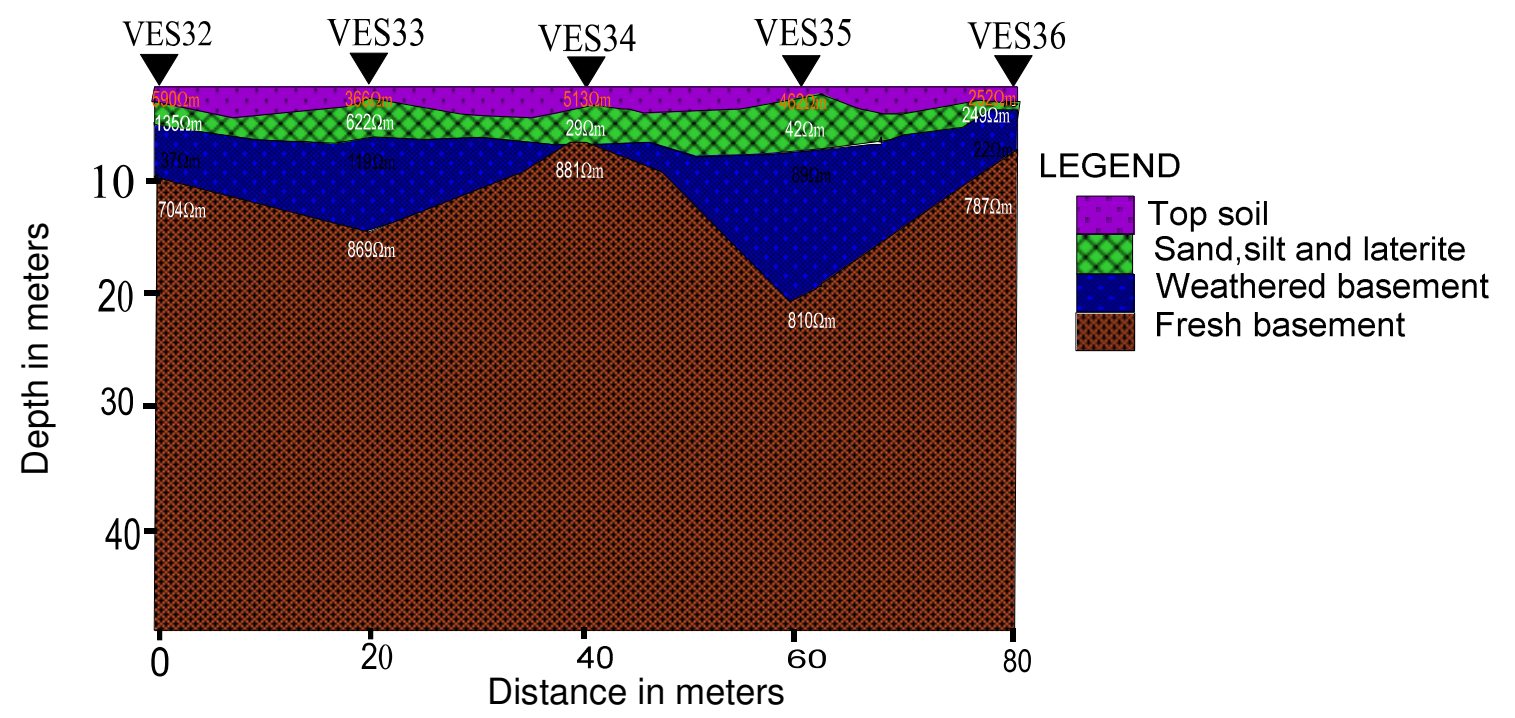

Figure 12: Geoelectric section along profile 8

\section{DISCUSSION}

\section{Profile 1}

The geoelectric section of profile 1 is shown in the Fig. 5. The section indicates a maximum of three geoelectric layers. The profile is $60 \mathrm{~m}$ long and has four VES points. The first layer is generally thin and having an average thickness of $1.20 \mathrm{~m}$. Its resistivity value varies from $80 \Omega \mathrm{m}$ to $155 \Omega \mathrm{m}$. This layer is the top soil which consists of clay and laterite. Underlying this is the second having resistivity value ranging from $254 \Omega \mathrm{m}$ to $553 \Omega \mathrm{m}$. The resistivity of this layer is lower than that of the second layer. This layer is regarded as the weathered basement. Finally, the third layer on the profile has resistivity value within the range of $397 \Omega \mathrm{m}$ to $1121 \Omega \mathrm{m}$. From characteristic resistivity of earth materials, the rocks within this area may constitute the fresh basement.

\section{Profile 2}

The geoelectric section of profile 2 is shown in Fig. 6 . The section indicates a maximum of four geoelectric layers. The profile is $60 \mathrm{~m}$ long and has four VES points. The first layer is thin having an average thickness of $1.63 \mathrm{~m}$. Its resistivity value varies from $217 \Omega \mathrm{m}$ to $1525 \Omega \mathrm{m}$. This layer is the top soil which consists of laterite. Underlying this is the second layer which is thicker than the first layer. Its thickness varies from $1.08 \mathrm{~m}$ under VES7 to $7.64 \mathrm{~m}$ under VES5. The resistivity of this layer varies from $58 \Omega \mathrm{m}$ to $1325 \Omega \mathrm{m}$. However, this layer has resistivity value lower than the first. It indicate that the layer consist of sandy clay, and silt sand. Underneath this layer is the third layer with resistivity value ranging from $155 \Omega \mathrm{m}$ to $285 \Omega \mathrm{m}$. The resistivity of this layer is lower than that of the first and second layer. This layer is regarded as the weathered basement. Finally, the fourth layer on that profile has a resistivity value within the range of $461 \Omega \mathrm{m}$ to $1724 \Omega \mathrm{m}$. From the resistivity of earth materials, the rocks within this area may constitute the fresh basement. 


\section{Profile 3}

The geoelectric section of profile 3 is shown in Fig. 7 . A maximum of four geoelectric layers are delineated. The first layer has average thickness of about $2.10 \mathrm{~m}$. Its resistivity value varies from $85 \Omega \mathrm{m}$ to $375 \Omega \mathrm{m}$. This layer is the top soil which consists of sandy clay and silt sand. The second layer has average thickness of $6.10 \mathrm{~m}$. It has resistivity value ranging from $25 \Omega \mathrm{m}$ to $416 \Omega \mathrm{m}$. The layer is clay, sand and silt. Underneath this layer, is the third layer having resistivity value of $416 \Omega \mathrm{m}$ to $719 \Omega \mathrm{m}$. However, this layer is not present under VES9, VES10 and VES12. This layer is the weathered basement. Finally, the fourth layer is the fresh basement from characteristic resistivity values of earth material and has a resistivity value ranging from $394 \Omega m$ to $6397 \Omega m$.

\section{Profile 4}

The geoelectric section of profile 4 is shown in Fig.8. The profile is a combination of different layers ranging from a minimum of two to a maximum of four. The first layer has an average thickness of about $1.20 \mathrm{~m}$. Its resistivity value range from $85 \Omega \mathrm{m}$ to $303 \Omega \mathrm{m}$. This layer is the top soil which consists of sandy clay and silt sand. The second layer has a thickness of $0.79 \mathrm{~m}$ under VES15 to $3.94 \mathrm{~m}$ under VES16. It has resistivity value ranging from $35 \Omega \mathrm{m}$ to $205 \Omega \mathrm{m}$. This value of resistivity is within the range of resistivity of clay and silt. Underneath this layer, is the third layer having resistivity value ranging from $25 \Omega \mathrm{m}$ to $650 \Omega \mathrm{m}$. This layer is regarded as the weathered basement. Finally, the fourth layer is the fresh basement and has a resistivity value ranging from $211 \Omega \mathrm{m}$ to $900 \Omega \mathrm{m}$.

\section{Profile 5}

The geoelectric section of profile 5 is shown in Fig.9. The section indicates a maximum of three geoelectric layers. The profile is $80 \mathrm{~m}$ long and having five VES point. The first layer is generally thin having an average thickness of $1.40 \mathrm{~m}$. Its resistivity value varies from $402 \Omega \mathrm{m}$ to $788 \Omega \mathrm{m}$. This layer is the top soil which consists of laterite. Underlying this is the second layer which is thicker than the first, this layer having resistivity value ranging from $107 \Omega \mathrm{m}$ to $913 \Omega \mathrm{m}$. This layer is regarded as the weathered basement. Finally, the third layer on the profile has resistivity value within the range of $560 \Omega \mathrm{m}$ to $949 \Omega \mathrm{m}$. From characteristics resistivity of earth materials, the rocks within this area may constitute the fresh basement.

\section{Profile 6}

The geoelectric section of profile 6 is shown in Fig. 10. The section indicates a maximum of four geoelectric layers. The profile is $80 \mathrm{~m}$ long and having five VES point. The first layer is generally thin having an average thickness of $1.80 \mathrm{~m}$. Its resistivity value varies from $102 \Omega \mathrm{m}$ to $679 \Omega \mathrm{m}$. This layer is the top soil which consists of laterite. Underlying this is the second layer which is thicker than the first. Its thickness varies from $1.45 \mathrm{~m}$ under VES24 to $4.59 \mathrm{~m}$ under VES25. The resistivity of the layer varies from $24 \Omega \mathrm{m}$ to $704 \Omega \mathrm{m}$. This layer consists of sand silt and laterite. Underneath this layer is the third layer having resistivity value ranging from $27 \Omega \mathrm{m}$ to $769 \Omega \mathrm{m}$. This layer is regarded as the weathered basement. Finally, the fourth layer on the profile has resistivity value within the range of $796 \Omega \mathrm{m}$ to $965 \Omega \mathrm{m}$. From characteristic resistivity of earth materials, the rocks within this area may constitute the fresh basement.

\section{Profile 7}

The geoelectric section of profile 7 is shown in Fig. 11. The section indicates a maximum of four geoelectric layers. The profile is $80 \mathrm{~m}$ long and having five VES point. The first layer is generally thin having an average thickness of $1.83 \mathrm{~m}$. Its resistivity value varies from $80 \Omega \mathrm{m}$ to $632 \Omega \mathrm{m}$. This layer is the top soil which consists of sand, silt and laterite. Underlying this is the second layer which is thicker than the first. Its thickness varies from $0.64 \mathrm{~m}$ under VES30 to $2.91 \mathrm{~m}$ under VES29. The resistivity of the layer varies from $19 \Omega \mathrm{m}$ to $748 \Omega \mathrm{m}$. This layer consists of clay and gravel. Underneath this layer is the third layer having resistivity value ranging from $27 \Omega \mathrm{m}$ to $769 \Omega \mathrm{m}$. This layer is regarded as the weathered basement. Finally, the fourth layer on the profile has resistivity value within the range of $704 \Omega \mathrm{m}$ to $989 \Omega \mathrm{m}$. From characteristic resistivity of earth materials, the rocks within this area may constitute the fresh basement.

\section{Profile 8}

The geoelectric section of profile 8 is shown in Fig. 12. The section indicates a maximum of four geoelectric layers. The profile is $80 \mathrm{~m}$ long and having five VES point. The first layer is generally thin having an average thickness of $1.45 \mathrm{~m}$. Its resistivity value varies from $252 \Omega \mathrm{m}$ to $590 \Omega \mathrm{m}$. This layer is the top soil which consists of laterite. Underlying this is the second layer which is thicker than the first. Its thickness varies from $1.37 \mathrm{~m}$ under VES36 to $4.06 \mathrm{~m}$ under VES34. The resistivity of the layer varies from $29 \Omega \mathrm{m}$ to $622 \Omega \mathrm{m}$. This layer consists of sand, silt and laterite. Underneath this layer is the third layer having resistivity value ranging from $22 \Omega \mathrm{m}$ to $881 \Omega \mathrm{m}$. This layer is regarded as the weathered basement. Finally, the fourth layer on the profile has resistivity value within the range of $704 \Omega \mathrm{m}$ to $869 \Omega \mathrm{m}$. From characteristic resistivity of earth materials, the rocks within this area may constitute the fresh basement. The resistivities of the profiles range from $22 \Omega \mathrm{m}$ to $6397 \Omega m$ which closely agreed with Kumar et al., (2014).

\section{Determination of Cassiterite potential}

The mineral cassiterite, $\mathrm{SnO}_{2}$ is the most important ore of tin. It is an economic mineral weathered from the ring complexes of Dutsen-wai. This mineral has a greasy luster and seems to be heavy in the hand. The weathered cassiterite is denser than the silt and sand, as a result of its high density, the cassiterite sink to the bedrock with other high density mineral to form the model of alluvial deposits which are suspected to be in the depression on the bedrock. From the above information, all the area with high depressions on the weathered basement along the eight profiles is suspected to be the area of high cassiterite potential. 
The 3D surface in (Fig.13) indicates the various sounding point and their expected depth to the bedrock which shows the sub-surface basement of the area. The map in (Fig.14) indicates the sounding point with high cassiterite potential which point out most likely area to drill if the need for that arise.

The purpose of this research is to locate points where high potential cassiterites are accumulated. Based on this, the map in (Fig. 14) shows the areas of high cassiterite potential.Statistics of the results show that eighteen (18) VES point out of the thirty six (36) VES point which depth range from $3 \mathrm{~m}$ to $9 \mathrm{~m}$ in (fig.14) are the areas of high Cassiterite potential.These results could be compared with the results of aeroradiometric study of Naraguta area, which give the highest count range to be between $3 \mu \mathrm{R}$ to $7 \mu$ R. These values could result from the Younger Granite rocks found in these areas which host some radioactive minerals like pyrochlore, thorite, zircon and monazite (accessory elements to tin), placer deposits of weathered sediments, the by-products of tin mining which are radioactive minerals and waste products of the mining activities(Akanbi,2012).
Detailed mapping and structural studies of the Younger Granite Complexes have revealed the pattern of tin mineralization. The cassiterite has been dispersed in multitudinous, narrow greisen veins, and quartz stringers in the roof zones of the biotite-granite intrusions, and is usually entrapped within the parent rock beneath an impermeable cover of roof rocks (Akanbi, 2012). The sub-horizontal form of the roof sections of the ring-intrusions and plutons has apparently favoured a lateral dispersion of mineralization. Since the greater part of the primary mineralization is concentrated in the horizontal roof sections of the biotite-granites, it follows that erosion rapidly uncovers an extensive area of tin-bearing granite and thus facilitates the wide distribution of cassiterite in the surrounding drainage system. Many of the source rocks are situated on or near major watersheds, so that a wide spread of alluvial is further enhanced. So in order to produce a Cassiterite potential map, the elevation of the area needs to be considered (Akanbi, 2012). But in the present research Cassiterite mineralization map was produced (fig. 14) using electrical resistivity method.

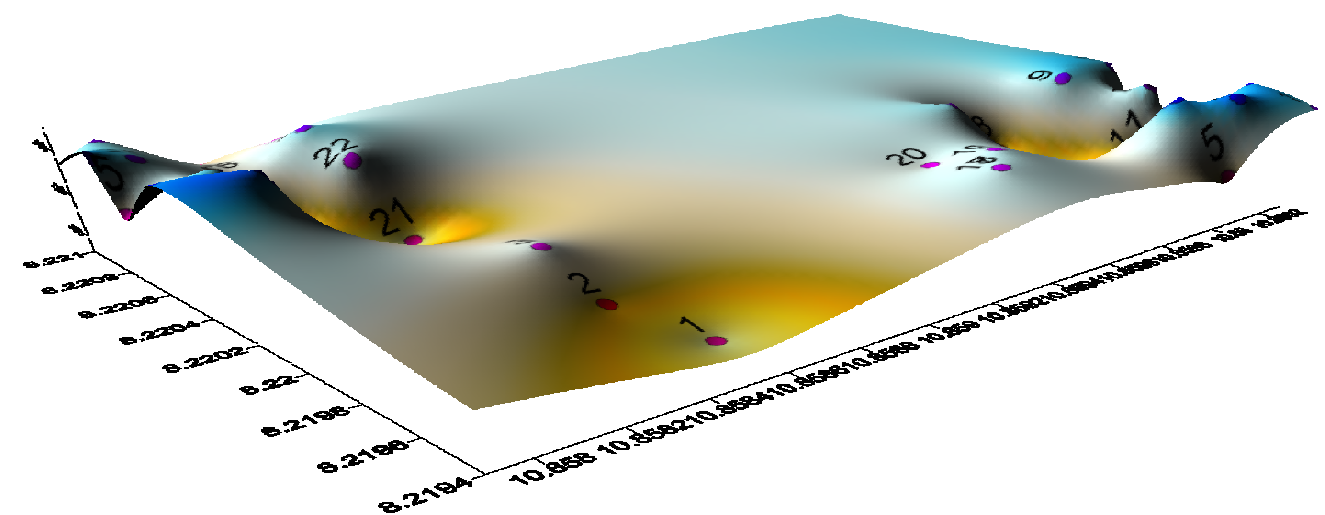

Figure 12: Basement Topography of the Study Area showing the Undulating Nature of the Bedrock Surface.

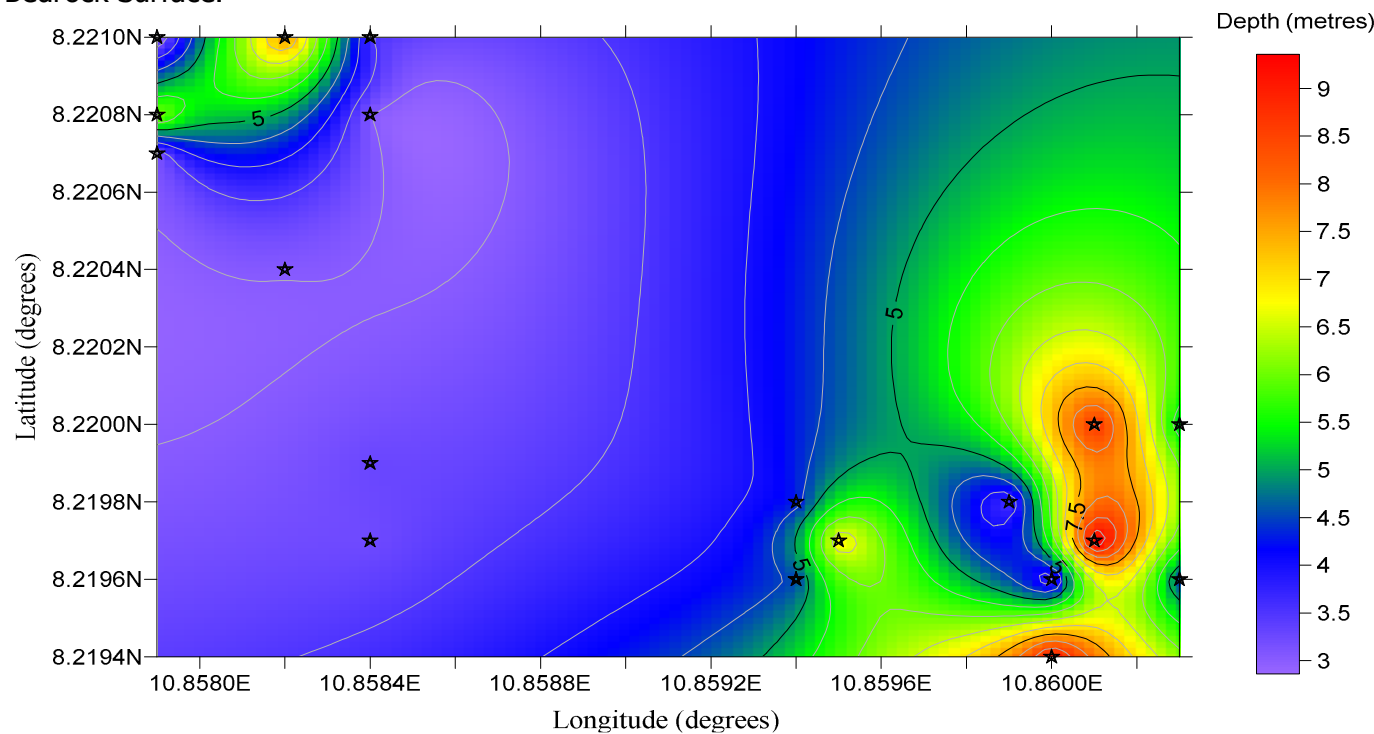

Figure 13: Cassiterite Mineralization Potential Map 


\section{Bajopas Volume 10 Number 2 December, 2017}

\section{CONCLUSION}

A total of thirty six (36) VES stations were established in this study. The interpretation of the sounding data indicates a minimum of three and a maximum of four geoelectric layers in the study area. The rock types of the study area comprises mostly of sandy clay, laterite, weathered and fresh basement. Thus, electrical resistivity method has proved useful in delineating the different subsurface geologic formations of varying thicknesses and conductivities. From the result of this work, the following objectives were achieved:

1. The top of the weathered basement is considered as the layer with high depression on the bedrock and its thickness varies from one profile to another. The thickness of the alluvial deposit sediment is within the overburden depth of the depression on the bedrock.

2. The VES points with high depression are considered as point of high cassiterite potential and the Cassiterite mineralization potential map in figure 13 identify the points.

The 3D surface identifies the various position of VES station and the expected depth of each of the VES point is also identified, which shows the sub-surface basement of the area.

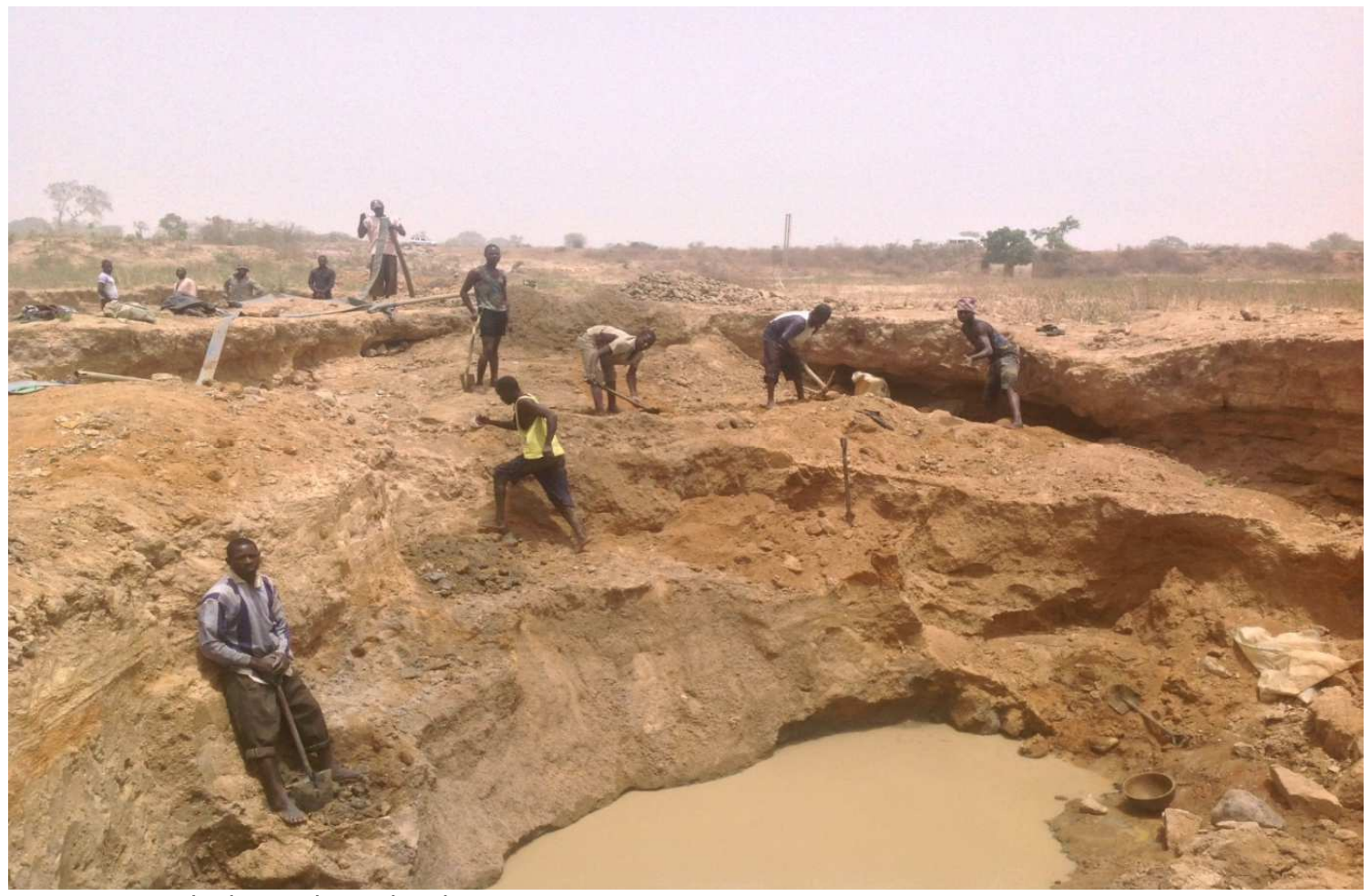

Figure 15: People digging by trial and error

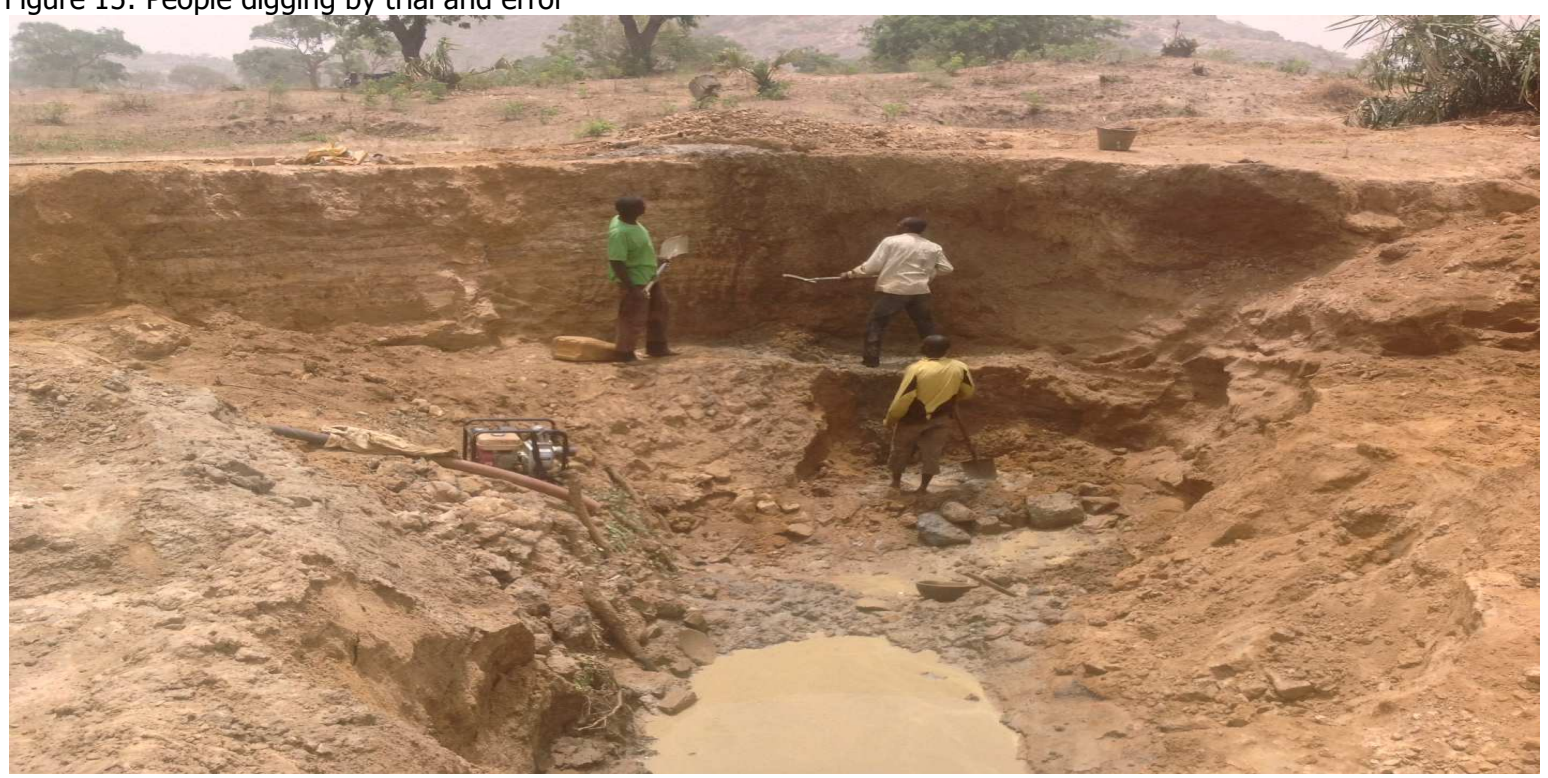

Figure 16: Location of the gravel sand containing the Cassiterite 
Bajopas Volume 10 Number 2 December, 2017

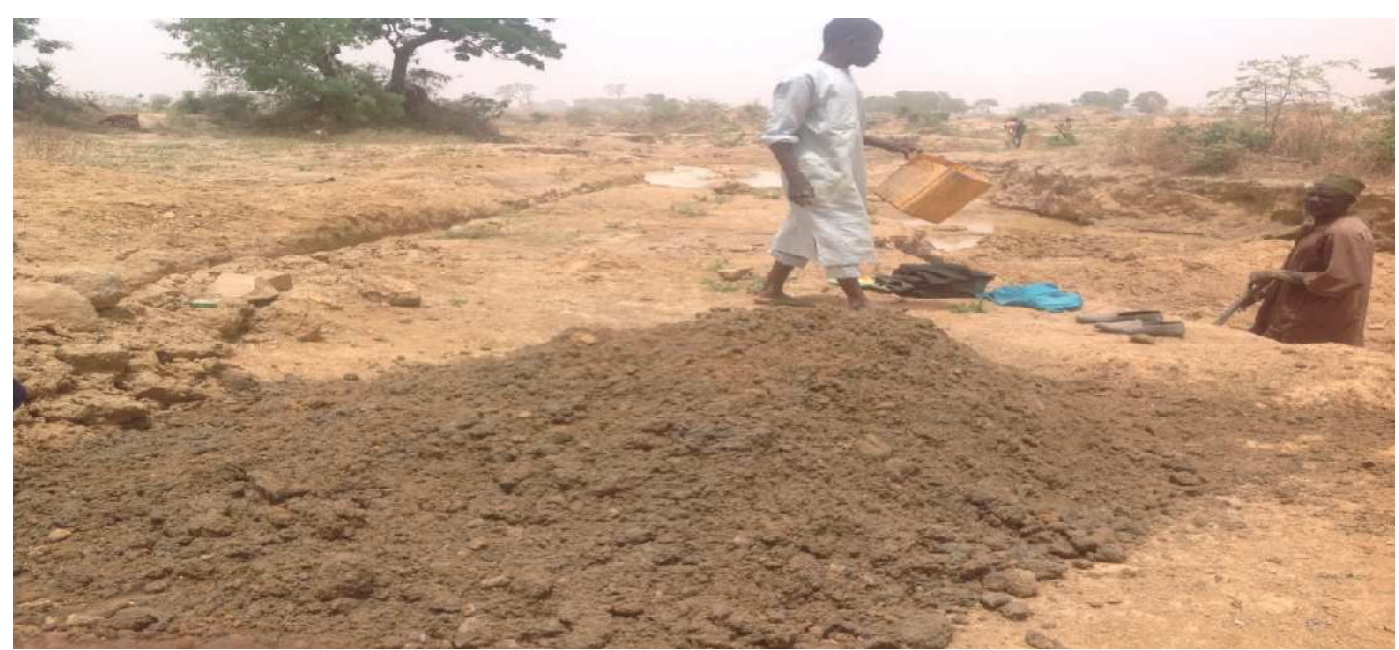

Figure 17: Gravel Sand containing the Cassiterite

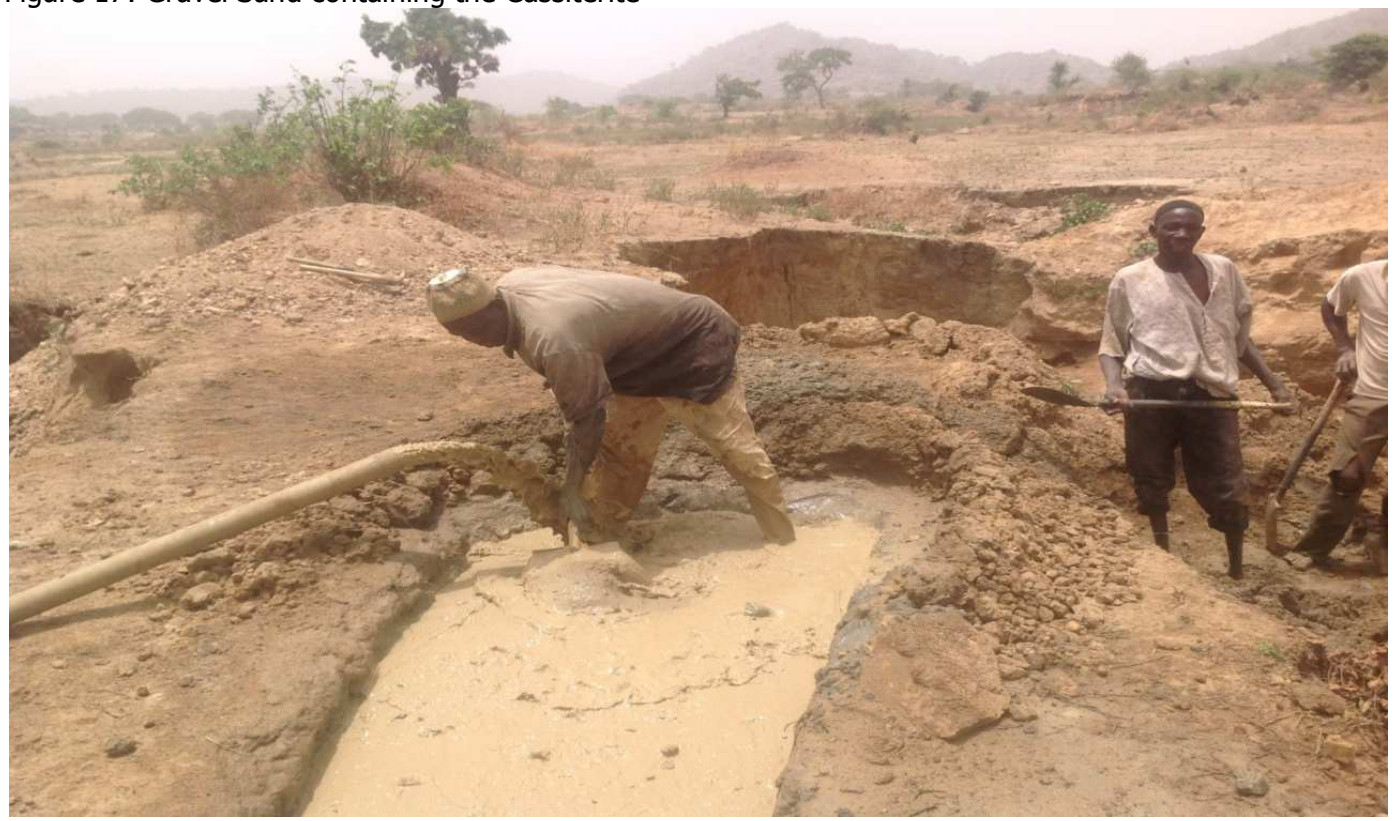

Figure 18: Local Separation of the Cassiterite from the gravel sand

\section{REFERENCES}

Abubakre, O.K. Sule, O.Y. and Muraina, R.A. (2009). Exploring the Potentials of Tailings of Bakaru cassiterite deposit for the production of Iron ore Pellets. Journal of Minerals and Materials characterization and Engineering; Vol. 8, 5, pp. 359-361.

Ahmed, A.L. (2006). Detailed Radiometric survey of the Albite Riebeckite granites of Dutsen-wai ring Complex. Unpublished Ph.D. Thesis, Department of Physics, Ahmadu Bello University, Zaria.

Aina, A. and Olarewaju, V. O. (1992). Geological interpretation of aeromagnetic data in some parts of north central Nigeria. Journal of African Earth Sciences, vol. 14, No 1,pp. 103-109.

Ajakaiye, D.E. and Sweeny, J.F. (1974). Three dimensional gravity interpretation of the Dutsen-wai Complex. Nigerian Younger Granite Province. Tectonophysics, Elsevier
Scientific Publishing Company, Amsterdam, Vol.24, pp. 331-341.

Akanbi, E. S. and Makama, E.K. (2011). Application of Least Squares Method (LSM) in the Separation ofAeroradiometric Anomalies of Naraguta area, Sheet 168, North Central Nigeria, Nigerian Journal of Physics. 1(18): 53-62

Akanbi, E.S.,Ugodulunwa, F.X.O. and Gyang, B.N. (2012). Mapping potential Cassiterite deposits of Naraguta Area, North central Nigeria Using Geophysics and Geographic Information System (GIS) Journal of Natural Science Research Vol. 8; pp. 132.

Black, R. and Girod, M., (1973). Late Paleozoic to Recent igneous activity in West Africa and its relationship to basement structure. In: T.N. Clifford and I.G. Gass (Editors), African Magmatism and Tectonics. Oliver and Boyd, Edinburgh, pp. 185-210. 
Brown, G.C. and Bowden, P. (1973). Experimental studies concerning the genesis of theNigerian Younger Granites. Contrib. Mineral. Petrol., 40: 131-139.

Cowie, A. (2010). Tin, an Overlooked commodity. The Market Oracle, Aug, 192010. http://www.marketoracle.co.uk.

Ekwe, A.C., Nnodu, I. N., Ugwumbah, K. I. and Onwuk, O.S. (2010). Estimation of Aquifer Hydraulic characteristics of low permeability formation from Geosounding data: A case study of oduma Town, Enugu State Nigeria. Medwell Journals, vol. 4, pp. 19-26.Doi: 10.3923/ojeci.2010.19.26

Falconer, J. D. (1921). Nigerian Tin, its Occurrence and Origin. Economic Geology, 7, 542-546.

Falconer, J. D. and Raeburn, C. (1923). The Nothern Tin Fields of Bauchi province. Journal of African Earth Science, Vol. 3, 223.

Jacobson, R. R. E. (1943). Report on Wolframite Investigation. Unpublished Geology Survey of Nigeria Report.

Jacobson, R. R. E. and Macleod, W. N. (1977). Geology of Liruei, Banke and adjacent Younger granite ring complexes. Geological Survey of Nigeria Bulleting 33: 1-117.

Kumar, R., Tiwari, A. K., Yadav, G.S. and Singh, N. P. (2014). Geohydrological Investigation using vertical Electrical Sounding at Banaras Hindu University Campus, Varansi, U. P India. International Journal of Research in Engineering and Technology. Vol. 3: pp. 252256.

Macleod, W.N. (1971). Geology of the Liruei, Banke and adjacent Younger Granite ring Complexes. Journal of African Earth Science, Vol. 3, 223.

Obaje, N. G. (2009). Geology and Mineral Resources of Nigeria, Lecture in Earth Sciences, 120, Springer-Verlag Berlin Heidelberg. doi: 10.1007/978-3-540-92685-6-3.

Oladapo, M. I. (2013). Hydro-geoelectric study of Ijare town Southwestern Nigeria. International Journal of water Resources and Environmental Engineering, vol. 5, pp. 687696. Doi: 10.5897/IJWREE2013.0424.

Ologe, M., (1971): Geomorphology of Zaria and its region, Department of Geography occasional paper, Ahmadu Bello University, Zaria.

Oyawoye, M.O. (1968). The geology of the Zaranda ring complex, northern Nigeria. Journal ofMineral Geology Nigeria. 3: 33-47.
Pastor, J. and Turaki, U.M. (1985). Primary Mineralization in Nigerian ring complexes and its economic significance. Journal of African Earth Science, Vol. 3, 1/2, pp. 223-227.

Raeburn, C., Bain, A.D.N. and Russ, W. (1927). The tinfields of Zaria and Kano provinces.Geol. Surv. Niger. Bull., 11.

Rodrigo Comino, J., Ruiz Sinogo, J. D., SencialesGonzáloz, J. M., Guerra-Merchán, A., Seeger, M., Ries, J. B. (2016). High variability of soil erosion and hydrological processes in Mediterranean hill slope vineyards (Montes de málaga, spain). CATENA 145,274-284. doi: 10.1016/j. Catena.2016.06.012.

Sultan, A.S.A. (2012). Groundwater Management by Using Hydro- Geophysical Investigation: Case Study: An Area Located at North Abu Zabal City, Hydrogeology - A Global Perspective, Dr. Gholam A. Kazemi (Ed.), ISBN: 978-95351 0048-5, InTech, Available from:http://www.intechopen.com/books/hyd rogeology a globalperspective/groundwater-management-byusing-hydro-geophysical- investigation-casestudy-an-arealocated-at-north.

Turner, D.C., (1963). Ring structures in the SaraFieryounger granite complex, northernNigeria. Q. J. Geol. Sot., London, 119: 345-366.

Turner, D.C.,(1972). Structure and tectonic setting of the younger granite ring complexes of Nigeria and southern Niger, Part I: ring complexes and their component units.Savanna, 1: 223-236.

Turner, D.C., Bowden, P., Bagnett, J. N., Ike, E. C., Abaa, S.I., Kinnaird, J.A., Abernethy, C.A., Badejoko, T.A. and Moyes, A.B. (1978). The northern Nigeria Ring Complexes. St. Andrews University Younger Granite Research group (1973-1978).

Van Breeman, O. and Bowden, P. (1973). Sequential age trends for some NigerianMesozoic granites. Nature, 242: 9-11.

Zohdy A (1965). The Auxiliary Point Method of Electrical Sounding Interpretation, and Its Relationship to the Dar Zarrouk Parameters. Geophysics 30(4):644-660. doi: 10.1190/1.1439636. 